\author{
M.A. Ualiyeva ${ }^{1}$, D.I. Syzdykova ${ }^{2^{*}}$ \\ ${ }^{I}$ L.N. Gumilyov Eurasian National University, Kazakhstan \\ ${ }^{2}$ Karagandy University of the name of academician E. A. Buketov, Kazakhstan \\ 'meirgul_96@bk.ru, ${ }^{2}$ nochochek@mail.ru \\ ${ }^{1}$ http://orcid.org/0000-0002-6731-8705, ${ }^{2}$ http://orcid.org/0000-0001-6547-9639 \\ ${ }^{2}$ Scopus Author ID: 1598245623139
}

\title{
Land tax as the main element of the economic mechanism for efficient land management
}

\section{Annotation}

Object: To review the impact of land tax on the efficiency of agricultural development. To review the procedure for calculating land tax in Kazakhstan. To study the features of land tax collection. To consider improving the taxation of agricultural land resources.

Methods: During the course of the study, we used statistical data analysis and methods of comparative analysis.

Findings: This paper reviews the aspects of agricultural land plots taxation. We have analyzed a number of factors affecting the effective taxation of land resources in Kazakhstan. We have performed a comparative analysis of land taxation in the EAEU countries. We have identified key components affecting land taxation and the main parameters of their functional efficiency.

Conclusions: This paper analyzes the current state of land taxation. We have developed proposals for the development of land taxation and improvement based on cadastral valuation. The results of the study allow us to conclude which of these aspects affect the effective land management.

Keywords: Base rate, special tax regime, land tax, single land tax, object of taxation, land plot, tax rate, tax benefits, soil quality score, cadastral value.

\section{Introduction}

Effective incentives for land taxation should form the basis for the development of land relations in Kazakhstan and increasing the competitiveness of its economy. To a great extent, the system of land taxation is merely fiscal in nature and does not encourage the efficient management of land resources; there are no benefits for agricultural land users, depending on how efficiently they manage land resources.

Kazakhstan's experience on the introduction of land tax has shown that the tax legislation has a number of weaknesses to it, while the land tax itself, in its current form, no longer corresponds to economic realities. Taxation of land resources requires Kazakhstan to improve the efficiency of their use. Currently, land quality steadily tends to deteriorate, the content of humus, nutrients, vegetation species composition and its productivity decreases, which reduces the potential of agricultural production, while there is no significant improvement in this issue due to the lack of financing.

At the same time, the study of land taxation and the development of proposals for regulating this phenomenon in Kazakhstan features characteristics of most countries at the formation stage.

\section{Literature review}

In the course of the research, we have analyzed scientific papers on land taxation by Russian and foreign scientists: Mashael M., Weith T., Barkmann T., Gaasch N., Rogga S, Strauß C., Zscheischler J. Ivanov N. etc.

Local authors studying land taxation and carrying out research: M.Kh. Zhanbusinova, G.A. Mayrimova, Zh.T. Seyfullin, R. Dithard, A. Musayeva, R. Karenov, A. Aoulov, R. Andarova, T. Ischuk, etc., as well as statistics published in local and foreign periodicals.

\section{Results}

The significance of the land tax for agricultural production is related to the use of land as the main means of production, in contrast to other industries, for which land is the space where economic activity takes place. (Mashael, M. (2020)

\footnotetext{
${ }^{*}$ Corresponding author.

E-mail address: nochochek@mail.ru
} 
Tax policy takes one of the leading places in state regulation of effective land management. Land, the main wealth of any state, is of particular importance in the conditions of the Republic of Kazakhstan.

Nowadays, agricultural producers hold agricultural land leases with the state for a period of 49 years. These leases can be extended after the initial period expiration. In this way, with legally established state ownership of agricultural land, the lessee becomes an actual owner (Shurr A. 2018). 111

1. One of the features of a land value tax in Kazakhstan is the availability of special tax regime for farm households on the basis of payment of the single land tax, where the product is the cultivation and production of agricultural products, the presence of land plots in private property rights and (or) land use. The purpose of the land tax is to provide economic methods for the rational land management and generation of budget revenues for the implementation of measures for land management, increasing the fertility of land, their protection, and for the socio-cultural development of the territory. Land Code of the Republic of Kazakhstan 2003).

Land tax payers are individuals and legal entities having objects of taxation:

2. On the right of ownership;

3. On the right of permanent land use;

4. On the right of primary gratuitous temporary land use (Land Code of the Republic of Kazakhstan 2003).

Land fees are charged in three forms: Land tax, rent, and standard land price. Let us take a closer look at the land tax. Annual land tax is levied on landowners, landholders and land users, except for tenants. This tax is applied to agricultural land based on its composition, quality, and location. Land taxation in Kazakhstan is currently carried out in accordance with the Code of the Republic of Kazakhstan "On taxes and other mandatory payments to the budget" in the form of annual fixed payments per unit of land area.

Next, let us compare the land tax legislation in the EAEU member states. The Republic of Armenia, the Republic of Belarus, and the Republic of Kazakhstan have a two-level tax system (republican and local levels); the Kyrgyz Republic and the Russian Federation have a three-level tax system (state-federal, regional, and local levels).

Table 1. System of taxation of agricultural producers in the EAEU member states

\begin{tabular}{|l|l|l|l|l|l|}
\hline $\begin{array}{c}\text { Taxation } \\
\text { system }\end{array}$ & $\begin{array}{l}\text { The Republic } \\
\text { of Armenia }\end{array}$ & The Republic of Belarus & $\begin{array}{c}\text { The Republic of } \\
\text { Kazakhstan }\end{array}$ & $\begin{array}{c}\text { The Kyrgyz } \\
\text { Republic }\end{array}$ & $\begin{array}{c}\text { The Russian } \\
\text { Federation }\end{array}$ \\
\hline $\begin{array}{l}\text { Special tax } \\
\text { treatment }\end{array}$ & Land tax & $\begin{array}{l}\text { Single tax for producers of } \\
\text { agricultural products }\end{array}$ & Single land tax & Land tax & Unified agricultural tax \\
\hline Tax base & $\begin{array}{l}\text { Land area } \\
\text { its estimatiplied by } \\
\text { value }\end{array}$ & $\begin{array}{l}\text { Monetary expression of } \\
\text { gross revenue from sales } \\
\text { (works and services) and } \\
\text { non-operating income }\end{array}$ & $\begin{array}{l}\text { Land area multiplied } \\
\text { by its estimated value }\end{array}$ & $\begin{array}{l}\text { Land area } \\
\text { multiplied by } \\
\text { the land tax } \\
\text { rate }\end{array}$ & $\begin{array}{l}\text { Monetary expression } \\
\text { of the incomes, re- } \\
\text { duced by size of ex- } \\
\text { penses }\end{array}$ \\
\hline Tax rate & 0 & $1,0 \%$ & No more than $0,5 \%$ & 0 & $6,0 \%$ \\
\hline
\end{tabular}

Note: (Analysis of the current regulatory systems of the agri-food market in the EAEU member states in terms of taxation, lending, insurance, price regulation and the licensing system. 2015)

Tax legislation states the taxation principles for agricultural producers of the Parties have a common basis, i.e. the level of tax burden for this category of economic entities is significantly lower than under the generally established regime (agricultural producers receive a special preferential tax system). At the same time, the Parties have different basic tax rates. Since January $1^{\text {st }}, 2012$, the Republic of Belarus has been seeing a reduction in the income tax rate. Previously, the income tax rate was $24 \%$, which is $6 \%$ more than the current one.

Thus, the Kyrgyz Republic has the lowest rate of 10\%, and since 2013, the profit rate in the Republic of Belarus has been 18\% compared to the Russian Federation and 20\% to the Republic of Kazakhstan.

Along with the special tax regime, Kazakhstan has a regime that exempts farms and individual farmers from all types of taxes, replacing them with a single land tax, the calculation base for which is the land plot area multiplied by estimated value. Tax rates under this regime never exceed $0.5 \%$. Land tax calculation is based on the land plot area multiplied by the estimated value. Thus, of the above-mentioned mechanisms for paying a Single tax, the one used in the Republic of Kazakhstan within the framework of the Single land tax appears to be the most profitable and easy to use.

The positive side of this mechanism is that it offers simple financial reporting, unlike the tax mechanism. In the Republic of Kazakhstan, agricultural land is subject to land tax. They are charged only land tax, 
which is set as a percentage of the cadastral value of land owned and/or used. No other tax applies. (Analysis of the current regulatory systems of the agri-food market in the EAEU member states in terms of taxation, lending, insurance, price regulation and the licensing system. 2015).

Basic land tax rates for agricultural land, industrial land, and other non-agricultural land located outside of built-up areas, as well as some other categories, are set per hectare and differentiated based on natural soil fertility expressed in bonitet points. (Consolidated analytical report on the state and use of land in the Republic of Kazakhstan for 2018).

Farms and agricultural holdings in Kazakhstan have a progressive tax rate ranging from $0.15 \%$ to $0.6 \%$ depending on the land plot area. (Andarova R.K. 2016).

Basic land tax rates for built-up areas are set per square meter of area depending on the area category.

A simplified system in the form of a single land tax can be applied for farms and agricultural holdings, that is calculated depending on the cadastral (estimated) value of agricultural land $(0.1 \%)$. (Consolidated analytical report on the state and use of land in the Republic of Kazakhstan for 2018).

The Land code of the Republic of Kazakhstan provides the following definition: "Agricultural land is recognized as land provided for the needs of agriculture or intended for these purposes. Agricultural land includes agricultural areas and land occupied by on-farm roads, communications, closed reservoirs, land reclamation network, buildings and structures necessary for the functioning of agriculture, and other land. (Land Code of the Republic of Kazakhstan 2003).

As is evident, agricultural land is recognized as land provided for the needs of agriculture or intended for these purposes. This definition shows that the category of agricultural land is represented by two types:

- Land provided for agriculture needs;

- Land intended for these purposes, i.e., those that can be used for the production of agricultural products in terms of their quality.

According to Professor M.D. Spektor, agricultural land provided for agricultural purposes occupies a special position in the unified land fund of the country. A peculiarity here is that they determine the volume of food and raw materials produced for industry. Any reduction in this category of land leads to a decrease in agricultural products. (Spektor M.D. 2016).

The total agricultural land area in Kazakhstan in 2017 was 177.8 million hectares, including 146.9 million hectares of pasture fields, 26.7 million hectares of arable lands and fallows, and 4.2 million hectares of hayfields.

One of the agricultural land issues is that all regions of the Republic show a steady trend of land quality deterioration, a decrease in the content of humus, nutrients, vegetation species composition and its productivity, which reduces the potential of agricultural production. (State program for the development of the agroindustrial complex of the Republic of Kazakhstan for 2017-2021. 2017).

As one of the benchmarks, the previous industry program "Agribusiness-2020" has set an increase of grain yields to $14 \mathrm{c} / \mathrm{ha}$ in 2020 and to $20 \mathrm{c} /$ ha in 2030. These kinds of goals are quite achievable if domestic farmers are provided with affordable financing tools to purchase the necessary agricultural equipment, high quality fertilizers and increase crop rotation to reduce land degradation. (Karenov R. 2015).

We feel important to note that according to the UN, as a result of environmental degradation processes, 7-10 million hectares of arable land are irretrievably lost annually in the world, which is the basis of life for 21-30 million people (with the current norm of 0.3 hectares per person). The problem of soil depletion is relevant for developing countries, where the share of medium and highly depleted soils is usually around 20$30 \%$ (including 30\% in China, and 20\% in India). (Ayulov A. 2016).

The basic tax rates on agricultural land (except for land provided to citizens for personal subsidiary farming of dacha construction) are set per hectare and are differentiated by the quality of the soil expressed by bonitet points considering natural and economic zoning. (Land Code of the Republic of Kazakhstan. 2003).

Fixed rates of land tax per 0.01 ha apply for land provided to citizens for personal subsidiary farming, dacha construction, and gardening.

Basic tax rates for the built-up area lands are calculated per 1 sq. $\mathrm{m}$ of area depending on the cost of territory development, built-up area status, and the purpose of taxable land plots.

For industrial, transport, communications, defense, and other non-agricultural land, base rates are set per 1 ha of land area depending on the cost of developing new land of similar quality, instead of being withdrawn from agricultural turnover. 
Basic tax rates on agricultural land are set per 1 ha and are differentiated by the quality of the soil, in proportion to the bonitet points. A bonitet point is a conditional unit that expresses cadastral valuation of a land plot.

At the same time, data from the zoning scheme for agricultural territories based on natural and other conditions are taken into account as well. This includes landscape features, location, reclamation status, water availability, etc. (Seifullin Zh.T. 2018).

Another feature of setting tax rates in the Republic of Kazakhstan is that they depend on the bonitet point, i.e., on the level of economic value of the land plot, thereby determining the market component when calculating the final amount of land tax.

Feature of a land value tax in Kazakhstan is that special tax regime for farms or agricultural holdings can be applied on the basis of the single land tax, which applies to the activities of farms or agricultural holdings for the production of agricultural products (except excisable), in the presence on the territory of Kazakhstan of land plots on private and (or) land use rights. (Kolosov N. 2018).

Rather high are costs associated with a high share of arrears on property taxes and land tax from individuals and, accordingly, with the need for compulsory collection of these taxes. (Ischuk T. 2018). 13

In accordance with the tax legislation of the Republic of Kazakhstan, different land use tax rates apply for each category of farms.

For agricultural enterprises, basic rates on agricultural land are set per hectare and are differentiated by the quality of the soil. For the steppe and dry-steppe zone lands, basic rates of land tax are set from 0.48 to 202.65 tenge in proportion to the bonitet points. For the semi-desert, desert and foothill-desert zone lands, basic rates are set from 0.48 to 50.18 tenge in proportion to the bonitet points.

Basic tax rates for agricultural land provided to individuals for personal household (subsidiary) farming, gardening and dacha construction, including land for construction, are set in the following amounts:

1.20 tenge per 0.01 hectares for areas up to 0.50 hectares;

2. 100 tenge per 0.01 hectare for areas over 0,50 hectares.

Farms or agricultural holdings are entitled to independently choose one of the following tax regimes:

1. A special tax regime for farms or agricultural holdings;

2. A special tax regime for subjects of small business;

3. A generally established procedure.

The object of taxation for the calculation of a single land tax is the estimated value of a land plot set on the basis of the act of determining the estimated value of land plots issued by the authorized state body for land management.

Calculation of the single land tax by farms and agricultural holdings on arable land is made by applying progressive rates of $0.1 \%$ to $0.5 \%$ based on the total land plot areas to their total estimated value.

Table 2. Basic land tax rates in proportion to bonitet points in the Republic of Kazakhstan

\begin{tabular}{|l|l|}
\hline \multicolumn{1}{|c|}{ Bonitet points } & \multicolumn{1}{|c|}{ Tax rate, tenge } \\
\hline $1-10$ & $0.48-2.41$ \\
\hline $11-20$ & $2.89-4.82$ \\
\hline $21-30$ & $5.31-9.65$ \\
\hline $31-40$ & $14.47-24.12$ \\
\hline $41-50$ & $28.95-38.60$ \\
\hline $51-60$ & $43.42-53.07$ \\
\hline $61-70$ & $57.90-82.02$ \\
\hline $71-80$ & $86.85-110.97$ \\
\hline $81-90$ & $115.80-144.75$ \\
\hline $91-100$ & $149.57-193.00$ \\
\hline Over 100 & 202.65 \\
\hline Note: (Seifullin Zh. 2018) & \\
\hline
\end{tabular}

Non-agricultural land that is part of built-up areas, industry, specially protected natural areas, forest and water resources and is used for agricultural purposes is also taxed at the basic rates of agricultural use. In this case, calculating the tax is based not on category or location of the land plot, but the peculiarity of the scope of its specific functional and target application: the agriculture. (Seifullin Zh. 2018). 
Calculation of the unified land tax on pastures, natural hayfields and other land plots used in activities covered by the special tax regime is carried out by applying the rate of $0.2 \%$ to the total estimated value of land plots.

Table 3. Calculation of the unified land tax on arable land based on the total area of land plots to the total estimated value of land plots

\begin{tabular}{|c|c|l|}
\hline No. & Land area, ha & \multicolumn{1}{|c|}{ Tax rate } \\
\hline 1 & Below 500 & $0.15 \%$ \\
\hline 2 & 501 to 1,000 & $\begin{array}{l}0.15 \% \text { of the estimated value from } 500 \text { hectares }+0.3 \% \text { of the esti- } \\
\text { mated value from hectares over } 500 \text { hectares }\end{array}$ \\
\hline 3 & 1,001 to 1,500 & $\begin{array}{l}0.3 \% \text { of the estimated value from } 1,000 \text { hectares }+0.45 \% \text { of the } \\
\text { estimated value from hectares over } 1,000 \text { hectares }\end{array}$ \\
\hline 4 & 1,501 to 3,000 & $\begin{array}{l}0.45 \% \text { of the estimated value from } 1,500 \text { hectares }+0.6 \% \text { of the } \\
\text { estimated value from hectares over } 1,500 \text { hectares }\end{array}$ \\
\hline 5 & Over 3,000 & $\begin{array}{l}0.6 \% \text { of the estimated value from } 3,000 \text { hectares }+0.75 \% \text { of the } \\
\text { estimated value from hectares over } 3,000 \text { hectares }\end{array}$ \\
\hline
\end{tabular}

Using proposals of local executive bodies, local representative bodies have the right to increase the rates of the unified land tax, however, no more than ten times on agricultural land not used in accordance with the Land Code of the Republic of Kazakhstan.

Thus, calculation of the single land tax for 2017 is determined as follows:

- For arable lands, by applying the rates (set out in the table above) based on the total area of land plots to the total estimated value of land plots;

- For pastures, by applying a rate of $0.2 \%$ to the total estimated value of such pastures.

However, when calculating the single land tax, it is necessary to take into account the adjustment of rates established by local representative bodies.

Let us consider the characteristic features of the availability of agricultural land in various forms of legal entities in Kazakhstan. Agricultural enterprises (large farms): on average, land area can vary from 5 to 20,000 hectares. There are farms with 500,000 to 1 million hectares of land.

Farms (small and medium-sized farms): peasant farms in southern and northern regions differ markedly from each other in the size of the cultivated land area. On average, one farm's land area in the southern regions can vary from 3 to 500 hectares; in the northern regions from 50 to 10 thousand hectares or more. Farms of the rural population (small farms): usually, a private plot/vegetable garden with a size of 0.10 to 0.5 ha. (Dithard R. 2019).

According to the data presented on the website of the State Revenue Committee of the Ministry of Finance of the Republic of Kazakhstan, in general, there is an increase in budget revenues from land tax over the years. Nationwide, the receipt was 14,935.1 million tenge in 2015, 15,255.1 million tenge in 2016, $15,353.3$ million tenge in 2017, and for 10 months of 2018 it amounted to $14,801.5$ million tenge.

The largest tax revenues for land use by region were recorded in the city of Almaty $(2,820.1$ million tenge) and the Karaganda region (2,073.0 million tenge).

Table 4. Land tax receipts by regions for 2014-2018, million tenge

\begin{tabular}{|l|c|c|c|c|c|c|}
\hline \multicolumn{1}{|c|}{ Regions } & 2014 & 2015 & 2016 & 2017 & 2018 & $\begin{array}{c}\text { Deviation } \\
2018 / 2014, \%\end{array}$ \\
\hline \hline \multicolumn{1}{|c|}{1} & 2 & 3 & 4 & 5 & 6 & 7 \\
\hline Akmola & 487.6 & 392.0 & 283.7 & 283.7 & 434.9 & -9.7 \\
\hline Aktobe & 659.1 & 595.8 & 518.3 & 324.5 & 480.5 & -27.1 \\
\hline Almaty & 794.7 & 773.7 & 829.5 & 520.6 & 831.6 & +4.6 \\
\hline Atyrau & 455.1 & 481.6 & 499.9 & 403.1 & 476.5 & +4.7 \\
\hline East Kazakhstan & $1,401.9$ & $1,350.4$ & $1,364.1$ & $1,145.5$ & $1,183.1$ & -15.6 \\
\hline Zhambyl & 365.1 & 354.8 & 361.2 & 248.4 & 347.5 & -4.8 \\
\hline West Kazakhstan & 231.9 & 182.0 & 180.4 & 128.7 & 200.3 & -13.6 \\
\hline Karaganda & $2,660.1$ & $2,475.2$ & $2,475.0$ & $1,914.6$ & $2,073.0$ & -22.1 \\
\hline Kyzylorda & 270.3 & 273.1 & 290.3 & 239.5 & 296.4 & +9.6 \\
\hline Kostanay & 477.6 & 612.7 & 377.3 & 268.6 & 474.7 & -0.6 \\
\hline
\end{tabular}




\begin{tabular}{|l|c|c|c|c|c|c|}
\hline \multicolumn{1}{|c|}{1} & 2 & 3 & 4 & 5 & 6 & 7 \\
\hline Mangistau & 536.3 & 570.6 & 489.7 & 428.2 & 431.6 & -19.5 \\
\hline Pavlodar & $1,895.0$ & $1,885.9$ & $1,776.4$ & $1,365.9$ & $1,607.8$ & -15.1 \\
\hline North Kazakhstan & 402.3 & 288.9 & 262.1 & 206.6 & 386.6 & -3.9 \\
\hline Turkestan & $1,004.1$ & 948.9 & $1,132.8$ & 800.1 & $1,606.0$ & +60 \\
\hline City of Almaty & $2,247.5$ & $2,540.4$ & $3,032.6$ & $2,318.6$ & $2,820.1$ & +25.4 \\
\hline City of Astana & $1,287.8$ & $1,209.1$ & $1,247.5$ & $1,362.6$ & $1,150.9$ & -10.6 \\
\hline Total & $15,176.4$ & $14,935.1$ & $15,255.1$ & $11,959.1$ & $14,801.5$ & -2.4 \\
\hline Note: (http://www.minfin.gov.kz)
\end{tabular}

When considering land tax revenues by region, the largest decrease by $27.1 \%$ was noted in the Aktobe region. An increase in the tax was recorded in the Turkestan region. This increase was due to combining data with the former South Kazakhstan region. The second position of land tax increase was noted in the city of Almaty. This is associated with increased business activity in this region.

The low share of tax revenues to the budget from agricultural activities in some regions indicates a low tax base, which was caused by the unprofitability of many farms, or low profitability of production in them, which exacerbates the inability to fully utilize the resource potential. Short-term loans with high interest rates allow only current expenses to be realized, while implementation of expanded reproduction of land resources requires long-term funding.

To date, no changes have been made to the Tax Code of the Republic of Kazakhstan on the basic rates of payment for 1 ha (for agricultural land) and $1 \mathrm{~m}^{2}$ (for the built-up area land), which have not been changed for more than 10 years.

In the course of the ongoing reforms, the established peasant farms, their associations and cooperatives have significantly changed the structure of agricultural production. They produce half as much as individual farms. To date, households produce more than $50 \%$ of the gross agricultural output and the volume of their production increases annually (Table 1).

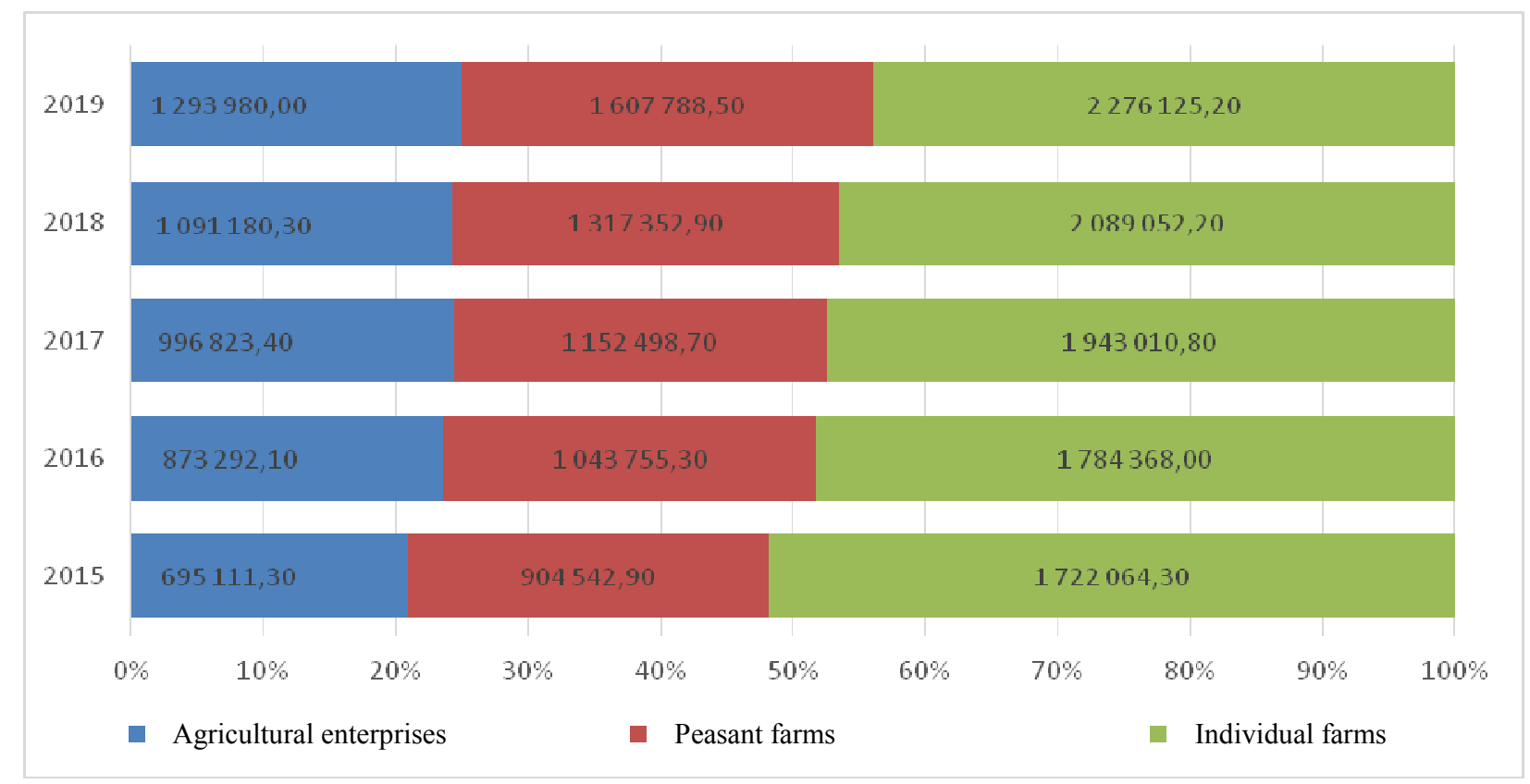

Fig. 1. Gross output of agricultural products (services), million tenge

Note: Compiled based on (https://stat.gov.kz, 2019)

Figure 1 shows that in 2015, peasant farms produced agricultural products for 904,542.90 million tenge, and households for 695,111.30 million tenge. Production volume at agricultural enterprises tends to increase.

In turn, we would like to note the problems as well. According to preliminary data of the Ministry of Agriculture of the Republic of Kazakhstan, the volume of gross agricultural output for 2019 increased by $0.9 \%$ compared to 2018 and amounted to 5,239.9 billion tenge. At the same time, production of livestock products increased by $4 \%$, and production of crop products decreased by $1.7 \%$. Specific problems of crop 
production are as follows: irrational use of arable land, fertilizing resources availability issues, insufficient number of granaries, deterioration of the phytosanitary situation, water supply and land condition issues. (Information and analytical review for the parliamentary hearings on the topic: "Issues of the development of the agro-industrial complex" in Nur-Sultan. 2020).

Currently, there are six types of tax regimes in agriculture. For peasant farms, there is a special tax regime based on a single land tax that is calculated taking into account the estimated value of the land plot. For agricultural producers, there is a special regime or $1-3 \%$ of sales depending on the enterprise form.

To improve the land taxation system, we propose to apply the coefficient to the cadastral value. We believe that changing the existing system of land taxation based on transitioning to calculating land tax depending on the cadastral value of land plots will meet the market requirements and encourage land users to rationally and efficiently use land resources and replenish the state budget. (Janbusinova M. 2015).

Local authorities are not sufficiently aware of the land owners, land plot areas, so it is difficult to determine the object of taxation and taxpayers. One of the reasons for this is the shared ownership of individuals, where determination of their respective shares appears difficult. Subsequently, cadastral registration and assessment for these lands appears just as difficult. Land tax performs an important function of replenishing the local budget.

Cadastral valuation is necessary for the formation of the tax base for land tax, while market price is necessary for its owner. Market price is an integral category, without which the land market cannot exist. A collateral price is necessary for the pledge of land as a guarantee for obtaining a loan, so one of the most effective ways to attract long-term loans in agriculture is to pledge a land plot. Therefore, a legislative procedure is necessary to regulate these economic categories in matters of land use, since it is the purchase and sale, lease, and pledge of land that express the right of ownership of a land plot.

To solve the above issues, we propose to establish a single agricultural tax that combines eight types of payments (VAT, CIT, groundwater tax, social tax, transport tax, corporate property tax, agricultural land tax, environmental emission charges). Its size should be determined on the basis of the land type, the bonitet point or cadastral value, and the share of the received income. This will create economic incentives for a more efficient use of land and will help to bring the sector out of the shadows.

\section{Discussion:}

The identified features of domestic competition and the proposed ways to improve the domestic economy's competitiveness can be considered for the formation of state programs for the competition development. It was necessary to eliminate a whole number of bureaucratic issues and provide the possibility of using leased land property as collateral when obtaining a loan. The goal is also to provide land that has not been used before, and thus increase the level of agricultural production.

\section{Conclusion:}

Research on the effective use of land resources taxation as a basis for sustainable rural development has shown the following:

- The current system of land taxation of agricultural objects does not meet the objectives of the introduction: land tax is not an incentive for production. The tax also does not function as an equalizer for the activity conditions of agricultural producers on the one hand, and other economic entities on the other.

- The existing approach to the calculation of land tax in the Republic does not contribute to the intensive development of agriculture and does not play a regulatory role. Revenues from the land tax are small and do not contribute to the regulation of agricultural production related to land protection, increasing its fertility, cash payments to agricultural producers working in worse conditions, etc.

- The economic aspect of land relations regulation consists in the implementation of the principle of paying land use through land taxation and rent, land valuation and price zoning, which allow conducting market operations with land, and selling land plots to the state and land use rights, and developing mortgage (collateral) lending to the peasantry. Assessment of land and establishment of the procedure for withdrawal allow the buy back and compensation for losses and damage, both to land users and the state.

- In the current conditions, it is extremely relevant to strengthen the role of the land tax as an important source of formation of the revenue part of local budgets, and to address the issue of its administration and further improvement of the collection mechanism. A solution to these issues will contribute to the improvement of its distribution, and therefore, equalization of economic conditions of farming in lands different by quality and location, growth in agriculture, preservation and increase of fertility, which ultimately will contribute to a significant increase in the revenues of the land tax to local budgets of RK. With the further devel- 
opment and expansion of the market economy, improvement of land relations, development of a legal framework in terms of land ownership and use, tax revenues from land use will grow.

\section{References}

Analiz dejstvuyushchih sistem regulirovaniya agroprodovol'stvennogo rynka $\mathrm{v}$ gosudarstvah-chlenah EAES $\mathrm{v}$ chasti nalogooblozheniya, kreditovaniya, strahovaniya, cenovogo regulirovaniya i razreshitel'noj sistemy [Analysis of the current regulatory systems of the agri-food market in the EAEU member states in terms of taxation, lending, insurance, price regulation and the licensing system]. 2015 [in Russian].

Andarova, R. \& Musina, S. (2016). Osobennosti razvitiya individualnih predprinimatelei i krestyanskih, fermerskih hozyaistv v Respublike Kazahstan [Features of the development of individual entrepreneurs and peasant (farmer) households in the Republic of Kazakhstan]. Vestnik Karahandinskoho hosudarstvennoho universiteta. Seriya Ekonomika - [Bulletin of KSU (Economic series)]. 4(84), 92-100 [in Russian].

Ayulov, A. (2016). Problemi rosta proizvodstva selskohozyaistvennoi produkcii v Kazahstan [Problems of growth in agricultural production in Kazakhstan]. Vestnik Karahandinskoho hosudarstvennoho universiteta. Seriya Ekonomika - [Bulletin of KSU (Economic series)]. 2(82), 11-17 [in Russian].

Dithard, R. \& Musaeva, A. (2019). Agrarnyj sektor Kazahstana: problemy i perspektivy razvitiya [Agrarian sector of Kazakhstan: problems and development prospects]. Transformation of the economy of Kazakhstan. 214-218 [in Russian].

Gosudarstvennaya programma razvitiya agropromyshlennogo kompleksa Respubliki Kazahstan na 2017-2021 gody [State program for the development of the agro-industrial complex of the Republic of Kazakhstan for 2017-2021]. (2017). eurasiancommission.org. Retrieved from https://www.eurasiancommission.org/ru [in Russian].

Informacionno-analiticheskij obzor $\mathrm{k}$ parlamentskim slushaniyam na temu: «Voprosy razvitiya agropromyshlennogo kompleksa [Information and analytical review for the parliamentary hearings on the topic: Issues of the development of the agro-industrial complex]. 2020 [in Russian].

Ischuk, T.L. (2018). Analiz ispolzovaniya metodov ischisleniya i vzimaniya nalogov s dohodov fizicheskih lic v Rossii i Kazahstane [Analysis of the use of methods for calculating and levying taxes on personal income in Russia and Kazakhstan]. Vestnik Karahandinskoho hosudarstvennoho universiteta. Seriya Ekonomika - [Bulletin of KSU (Economic series)]. 3(91), 222-231 [in Russian].

Janbusinova, M. \& Meirimova, G. (2015). Sovershenstvovanie metodiki nalogooblozheniya zemel' naselennyh punktov v Respublike Kazahstan [Improvement of the methods of taxation of lands of settlements in the Republic of Kazakhstan]. Science and the world, Tom 1, № 4 (20) 103-104 [in Russian].

Karenov, R. (2015). Ideya «zelenogo» razvitiya kak odin iz glavnih prioritetov «Strategii razvitiya Kazahstana do 2050 goda» [The idea of "green development" as one of the main priorities of the Development Strategy of Kazakhstan until 2050]. Vestnik Karahandinskoho hosudarstvennoho universiteta (seriya Ekonomika) [Bulletin of KSU (Economic series)]. 2(78), 5-15 [in Russian].

Kolosov, N. (2018). Zemel'nyj nalog po zakonodatel'stvu Rossijskoj Federacii i Respubliki Kazahstan: sravnitel'nopravovoj analiz [Land tax under the legislation of the Russian Federation and the Republic of Kazakhstan: a comparative legal analysis]. Siberian Legal Bulletin. No. 1 (80). 33-37 [in Russian].

Mashael M. Al Saud. (2020). Sustainable Land Management for NEOM Region. Springer Nature Switzerland AG. 497523. Doi: $10.1007 / 978-3-642-14782-13$.

Ofitsialnyi sait Komiteta statistiki Ministrerstva natsionalnoy ekonomiki Respubliki Kazakhstan [Committee on Statistics of the Ministry of National Economy of the Republic of Kazakhstan]. 2020. stat.gov.kz. Retrieved from https://stat.gov.kz [in Russian].

Ofitsialnyi sait Ministerstva finansov Respubliki Kazahstan [Ministry of Finance of the Republic of Kazakhstan] minfin.gov.kz. Retrieved from http://www.minfin.gov.kz [in Russian].

Seifullin, Zh.T. (2018). Ekonomiko-pravovoj mekhanizm upravleniya zemel'nymi resursami [Economic and legal mechanism of land management]. Priority tasks and strategies for economic development, management and marketing": materials of the International scientific and practical conference. 347-349 [in Russian].

Shurr A. \& Nosonov A. (2018). Formation of market relations in the agro-industrial complex of the North Kazakhstan region of the Republic of Kazakhstan. Eurasian potential and new development opportunities in the context of global challenges: Петропавловск. 347-351.

Spector, M.D. (2016). Ocenka ispol'zovaniya zemel'nyh resursov. [Assessment of the use of land resources]. NurSultan: Foliant, 240-242 [in Russian].

Svodnyj analiticheskij otchet o sostoyanii i ispol'zovanii zemel' Respubliki Kazahstan za 2018 hod (2018) [Consolidated analytical report on the state and use of land in the Republic of Kazakhstan for 2018]. (http://www.aisgzk.kz/aisgzk/files/Svodnyi analiticheskii otchet 2017.pdf) [in Russian].

Weith T., Barkmann T., Gaasch N., Rogga S, Strauß C., Zscheischler J. (2019). Sustainable Land Management in a European. "Co-Design of Change and Innovation" 166-168. Doi: 10.4236/jep.2016.74045.

Zaklyuchitel'nyj otchet Kazahstana po Programme opredeleniya celevyh pokazatelej [Kazakhstan's Final Report on the LDN Target Setting Program]. (2018). knowledge.unccd.int. Retrieved from https:// knowledge.unced.int/sites/ [in Russian]. 
Zemel'nyj kodeks Respubliki Kazahstan ot 2003 g. [Land Code of the Republic of Kazakhstan 2003]. 2019 online.zakon.kz. Retrieved from https:// http://online.zakon.kz [in Russian].

\section{М.А. Уалиева, Д.И. Сыздыкова}

\section{Жер салығы жер ресурстарын тиімді пайдаланудың экономикалық механизмінің негізгі элементі ретінде}

\section{Аңдатпа}

Maқcambl: Жер салығының ауыл шаруашылығын дамытудың тиімділігіне әсерін қарастыру. Қазақстандағы жер салығын есептеу тәртібін қарастыру. Жер салығын салу ерекшеліктерін зерттеу. Ауыл шаруашылығындағы жер ресурстарына салық салуды жетілдіруді қарастыру.

Әдістері: Зерттеу барысында статистикалық деректерді талдау және салыстырмалы талдау әдістері қолданылды.

Нәтижелері: Мақалада ауыл шаруашылық жер учаскелеріне салық салу аспектілері зерттелген. Қазақстандағы жер ресурстарына тиімді салық салуға әсер ететін бірқатар факторларға талдау жүргізілді. ЕАЭО елдеріндегі жер салығы бойынша салыстырмалы талдау жасалды. Жер салығына әсер ететін негізгі компоненттер және олардың функционалдық тиімділігінің негізгі параметрлері анықталды.

Қорытынды: Мақалада жер салығының қазіргі жағдайы талданды. Кадастрлық бағалау негізінде жер салығын дамыту және жетілдіру бойынша ұсыныстар баяндалды. Жүргізілген зерттеу нәтижелері аталған аспектілердің қайсысы жер ресурстарын тиімді пайдалануға әсер етеді деген қорытынды жасауға мүмкіндік береді.

Кілm сөздер: базалық мөлшерлеме, арнайы салық режимі, жер салығы, біртұтас жер салығы, салық салу объектісі, жер учаскесі, салық мөлшерлемесі, салықтық жеңілдіктер, топырақ бонитетінің балдары, кадастрлық құны.

\section{М.А. Уалиева, Д.И. Сыздыкова}

\section{Земельный налог как основной элемент экономического механизма эффективного использования земельных ресурсов}

\section{Аннотация}

Цель: Рассмотреть влияние земельного налога на эффективность развития сельского хозяйства, а также порядок исчисления земельного налога в Казахстане. Изучить особенности взимания земельного налога. Рассмотреть совершенствование налогообложения сельскохозяйственных земельных ресурсов.

Memodbl: В ходе исследования использовались статистический анализ данных и методы сравнительного анализа.

Pезультаты: В статье изучены аспекты налогообложения на сельскохозяйственные земельные участки. Осуществлен анализ ряд факторов, влияющих на эффективное налогообложение земельных ресурсов в Казахстане. Дан сравнительный анализ по земельному налогообложению в странах ЕАЭС. Выявлены ключевые составляющие, влияющие на земельное налогообложение и основные параметры их функциональной эффективности.

Bыводы: В статье проанализировано современное состояние земельного налогообложения. Изложены предложения по развитию земельного налогообложения и совершенствованию на основе кадастровой оценки. Результаты проведённого исследования позволяют сделать вывод, какие из перечисленных аспектов влияют на эффективное использование земельных ресурсов.

Ключевые слова: базовая ставка, специальный налоговый режим, земельный налог, единый земельный налог, объект налогообложения, земельный участок, налоговая ставка, налоговые льготы, баллы бонитета почв, кадастровая стоимость.

\section{References}

Mashael., M. Al Saud. Sustainable Land Management for NEOM Region. [Текст] / M. Mashael, Saud Al. K. Springer Nature Switzerland AG. — 2020. — P. 497-523. — Doi: 10.1007/978-3-642-14782-13.

Weith T., Barkmann T., Gaasch N., Rogga S, Strauß C., Zscheischler J. [Текст] // Sustainable Land Management in a European. Co-Design of Change and Innovation. — 2019. — № 5. — P.166-168. — Doi: 10.4236/jep.2016.74045.

Анализ действующих систем регулирования агропродовольственного рынка в государствах-членах ЕАЭС в части налогообложения, кредитования, страхования, ценового регулирования и разрешительной системы. M., 2015. - 160 c. - (https://damu.kz).

Андарова Р.К. Особенности развития индивидуальных предпринимателей и крестьянских (фермерских) хозяйств в Республике Казахстан. [Текст] / Р.К. Андарова, С.Т. Мусина // Вестн. Караганд. ун-та. Сер. Экономика. - 2016. - № 4(84). - С. 92-100. 
Аюлов А. Проблемы роста производства сельскохозяйственной продукции в Казахстане. [Текст] / А.М. Аюлов, Г.А. Кожахметова, Н. Есмагулова // Вестн. Караганд. ун-та. Сер. Экономика. — 2016. — № 2(82). — С. 1117.

Государственная программа развития агропромышленного комплекса Республики Казахстан на 2017-2021 годы. - 2017. - (https://www.eurasiancommission.org).

Дитхард Р. Аграрный сектор Казахстана: проблемы и перспективы развития / Р. Дитхард, А. Мусаева // Трансформация экономики Казахстана. — Астана: Типогр. «IndigoPrint», 2019. — С. 368.

Жанбусинова М. Совершенствование методики налогообложения земель населенных пунктов в Республике Казахстан / М. Жанбусинова, Г. Мейримова // Наука и мир. - Волгоград, 2015. — С. 347-349.

Заключительный отчет Казахстана по Программе определения целевых показателей LDN. — Нyр-Султан, 2018. - 120 c. (https://knowledge.unccd.int/).

Земельный кодекс Республики Казахстан от 2003 г. Официальный интернет-ресурс Министерства сельского хозяйства РК. — (https://www.gov.kz).

Информационно-аналитический обзор к парламентским слушаниям на тему «Вопросы развития агропромышленного комплекса». - Нур-Султан, 2020.

Ищук Т.Л. Анализ использования методов исчисления и взимания налогов с доходов физических лиц в России и Казахстане. [Текст] / Т.Л. Ищук, А.С. Баймухаметова // Вестн. Караганд. ун-та. Сер. Экономика. - 2018. 一№ 3(91). - С. 222-231.

Каренов Р. Идея «зеленого» развития как один из главных приоритетов «Стратегии развития Казахстана до 2050 года» [Текст]. / Р. Каренов // Вестн. Караганд. ун-та. Сер. Экономика. — 2015. — № 2 (78). — С. 5-15.

Колосов Н.В. Земельный налог по законодательству Российской Федерации и Республики Казахстан: сравнительно-правовой анализ / Н.В. Колосов // Сибир. юрид. вестн. — № 1 (80). — 2018. — С. 33-37.

О повышении базовой ставки земельного налога и ставки единого земельного налога на неиспользуемые земли сельскохозяйственного назначения: Решение маслихата г. Алматы. - 2017. — № 72. - Алматы: Ақшам, 2017. - 18 марта. — № 34 .

Официальный сайт Комитета по статистике Министерства национальной экономики РК. — (http://stat.gov.kz)

Официальный сайт Министерства финансов Республики Казахстан. - (http://www.minfin.gov.kz)

Сводный аналитический отчет о состоянии и использовании земель Республики Казахстан за 2018 г. — 2018. 160 c. - (http://www.aisgzk.kz/aisgzk).

Сейфуллин Ж.Т. Экономико-правовой механизм управления земельными ресурсами / Ж.Т. Сейфуллин // Приоритетные задачи и стратегии развития экономики, менеджмента и маркетинга: материалы Междунар. науч.-практ. конф. - Алматы, 2018. - С. 347-349.

Спектор М.Д. Оценка использования земельных ресурсов / М.Д.Спектор. - Нур-Султан: Изд-во «Фолиант», 2016. - С. 300-310.

Шурр А. Формирование рыночных отношений в агропромышленном комплексе Северо-Казахстанской области Республики Казахстан / А. Шурр, А. Носонов // «Козыбаевские чтения - 2018: Евразийский потенциал и новые возможности развития в условиях глобальных вызовов»: Междунар. науч.-практ. конф., СКГУ им. М. Козыбаева. - 2018. - С. 347-349. 